\title{
Strategi Penerapan Prinsip Good Corporate Governance dalam Pengelolaan Perusahaan Daerah Di Kota Kendari
}

\author{
Strategies for Implementing Good Corporate Governance Principles in \\ Management of Regional Companies in Kendari City
}

\section{${\text { Zahrowati }{ }^{1} \text {, Idris Saputra }}^{2}$}

1. Universitas Halu Oleo, Indonesia. E-mail: zahraalha051@gmail.com

2. Universitas Halu Oleo, Indonesia.E-mail: idris saputra@rocketmail.com

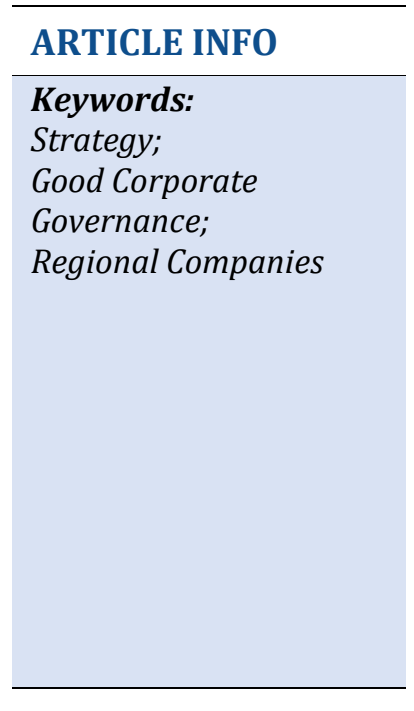

\section{INFO ARTIKEL}

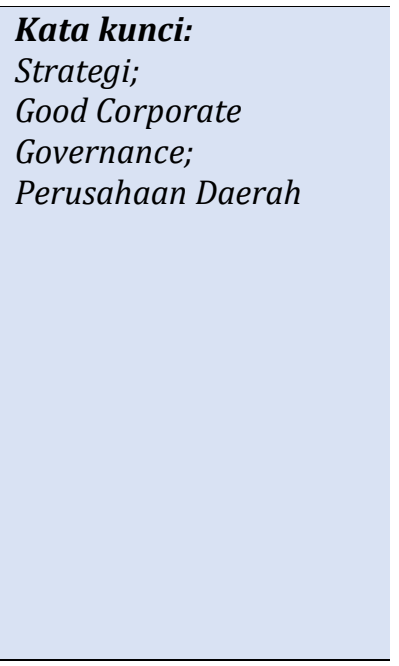

\begin{abstract}
This research is aimed to find the implementations of GCG in Kendari Regional Company Management and to find a concept related to GCG Principles implementation strategy in Kendari Regional Company Management. This research is a normative empirical research with statue approach. Based on the research can be concluded that (a) Finding Common ground between Regional Government and Regional Owned Enterprises about the importance of GCG principles implementation, (b) The importance for Local Regulation that specifically concern about the implementation of GCG Practice on Regional Owned Enterprise, (c) To amplify the role and authority of PD Pasar and PDAM Tirta Anoa by referring to Kendari City Regional regulation Number 3 Year 2004 concerning on Formation of Kendari City Market Regional Company and Local Water Company of Kendari City was established through Kendari City Regional Regulation Number 3 year 1976 concerning drinking water company of Kendari District Level II and Kendari City Regional Regulation Number 3 Year 2010.
\end{abstract}


Perusahaan Daerah Pasar Kota Kendari Tirta Anoa Kota Kendari dibentuk melalui Peraturan Daerah Kota Kendari Nomor 3 Tahun 1976 Tentang Perusahaan Air Minum (PAM) Daerah Kabupaten Tingkat II Kendari serta Peraturan Daerah Nomor 3 Tahun 2010.

\section{Pendahuluan}

Good Corporate Governance merupakan salah satu prinsip di dalam hukum perusahaan yang mengarahkan dan mengendalikan perusahaan agar mencapai keseimbangan antara kekuatan serta kewenangan perusahaan dalam memberikan pertanggungjawabannya kepada shareholders (pemegang saham) khususnya, dan stakeholders pada umumnya. Hal ini dimaksudkan untuk mengatur kewenangan direktur, manajer, pemegang saham, dan pihak lain yang berhubungan dengan perkembangan perusahaan. ${ }^{1}$

Prinsip ini juga dapat diartikan sebagai suatu konsep yang menyangkut struktur perseroan, pembagian tugas, pembagian kewenangan dan pembagian beban tanggung jawab dari masing-masing unsur yang membentuk struktur perseroan, dan mekanisme yang harus ditempuh oleh masing-masing unsur dari perseroan tersebut, serta hubunganhubungan antara unsur-unsur dari struktur perseroan itu mulai dari RUPS, direksi, komisaris, juga mengatur hubungan-hubungan antara unsur-unsur dari struktur perseroan dengan unsur-unsur di luar perseroan yang pada hakikatnya merupakan stakeholders dari perseroan, yaitu negara yang sangat berkepentingan akan perolehan pajak dari perseroan yang bersangkutan, dan masyarakat luas yang meliputi para investor publik dari perseroan itu (dalam hal perseroan merupakan perusahaan publik), calon investor, kreditor dan calon kreditor perseroan.

Tata kelola perusahaan atau yang lebih populer dikenal dengan istilah Corporate Governance didefinisikan secara umum oleh International Finance Corporation (IFC) sebagai "the structures and processes for the direction and control of companies. Berdasarkan pengertian tersebut, pada intinya tata kelola perusahaan membahas mengenai bagaimana cara suatu perusahaan diarahkan dan dikelola agar seluruh kepentingan pemangku kepentingan (stakeholders) diakomodasi secara baik. Maka dari itu, perusahaan harus dikelola dengan seimbang dan baik, sehingga timbul istilah Good Corporate Governance (GCG). ${ }^{2}$

Dalam penerapannya, prinsip Good Corporate Governance (GCG) ini adalah sistem yang mengatur mengelola dan mengawasi proses pengendalian usaha agar dapat berjalan secara berkesinambungan (sustainable), teratur guna menaikkan nilai saham, sebagai bentuk pertanggungjawaban kepada shareholders tanpa mengabaikan kepentingan stakeholders yang meliputi karyawan, kreditur dan masyarakat.

Ikatan Banking Indonesia, Manajemen Risiko 2 (Jakarta: Gramedia Pustaka Utama, 2015), 216.

2 Rinitami Njatrijani, Bagus Rahmanda, dan Reyhan Dewangga Saputra, "Hubungan Hukum dan Penerapan Prinsip Good Corporate Governance dalam Perusahaan,” Jurnal Gema Keadilan 6, no. 3 (2019): 248. 
BUMD (Badan Usaha Milik Daerah) adalah perusahaan yang didirikan dan dimiliki oleh pemerintah daerah. Sedangkan istilah BUMD menurut Pasal 331 Undang-Undang Nomor 23 Tahun 2014 adalah badan usaha yang seluruh atau sebagian besar modalnya dimiliki oleh daerah. ${ }^{3}$ Bentuk dari BUMD menurut undang-undang tersebut dapat berupa Perusahaan Umum Daerah (seluruh modalnya dimiliki oleh satu daerah) dan Perusahaan Perseroan Daerah (berbentuk PT dengan saham seluruhnya atau paling sedikit 51\% dimiliki oleh satu daerah).Sebagai salah satu pelaku ekonomi daerah, BUMD diharapkan menjadi salah satu penggerak bagi perekonomian daerah, antara lain melalui kegiatan usaha dalam rangka memenuhi kebutuhan masyarakat baik berupa barang maupun jasa.

Dalam upaya penguatan penerimaan daerah Kota Kendari yang bersumber dari kekayaan daerah yang bersumber dari kekayaan yang dipisahkan, maka peranan investasi pemerintah melalui BUMD sangat diharapkan, selain sebagai sumber PAD (pendapatan asli daerah), BUMD diharapkan juga sebagai penggerak utama pertumbuhan dan pembangunan ekonomi daerah (engine of growth) khususnya di Kota Kendari, sehingga mampu menimbulkan efek multiplier yang besar.

BUMD Kota Kendari sebagai perusahaan daerah dapat juga mengalami kerugian. Kerugian ini dapat disebabkan oleh buruknya pengelolaan perusahaan daerah karena dilakukan tanpa memperhatikan prinsip-prinsip good corporate government. Selain itu juga kerugian dapat disebabkan karena tidak berfungsinya sistem perencanaan dan pengendalian internal. 4

Dari berbagai literatur yang membahas good corporate governance dipahami bahwa konsep pemikiran yang membentuk lembaga atau institusi ekonomi ini terwujud dalam rangka untuk keberhasilan dunia usaha yang ditandai dengan terwujudnya nilai pemegang saham dalam jangka panjang serta memperhatikan stakeholder dan terwujudnya akuntabilitas. ${ }^{5}$ Institusi hukum dimaksudkan terdiri aturan-aturan yang mengatur tentang hubungan hukum antara pemegang saham, pengurus, pihak kreditur, pemerintah, karyawan serta para pemegang kepentingan internal dan eksternal lainnya. ${ }^{6}$

Dengan demikian tujuan dari prinsip good corporate governance adalah untuk mengarahkan dan mengendalikan jalannya perusahaan agar ideal menuju keberhasilan usaha dan akuntabilitas usaha. ${ }^{7}$

Berdasarkan uraian di atas, sehingga dapat ditarik titik fokus permasalahan mengenai strategi dalam penerapan prinsip good corporate governance bagi BUMD di Kota Kendari,

3 Sovia Hasanah, “Kepemilikan 100 Persen Saham BUMD oleh Satu Daerah,” HukumOnline.com, diakses Januari 10, 2020, https://www.hukumonline.com/klinik/detail/ulasan/lt59c1d986cb252/kepemilikan100-persen-saham-bumd-oleh-satu-daerah.

4 Turiman Fachturaman Nur, Terobosan Hukum Memajukan BUMD dalam Era Otonomi Daerah (Jakarta: Rajawali Garuda Pancasila, 2009), 12.

5 Suherman Toha, Penelitian Masalah Hukum Tentang Penerapan Good Corporate Governance Pada Dunia Usaha (Jakarta: Pusat Penelitian Dan Pengembangan Hukum Badan Pembinaan Hukum Nasional Departemen Hukum dan HAM RI, 2005), 2.

6 Ibid.

7 Ibid., 3. 
sehingga dapat dijadikan target pembenahan tatanan ekonomi daerah melalui BUMD dalam rangka meningkatkan PAD (pendapatan asli daerah) dan akuntabilitas Perusahaan Daerah sebagai BUMD di Kota Kendari.

Untuk memecahkan masalah tersebut, maka penelitian ini akan peneliti bagi dalam 3 tahap, yaitu:

1. Menelusuri penerapan prinsip good corporate governance dan hambatan apa saja yang dihadapi dalam menerapkan prinsip GCG di 2 perusahaan Daerah Kota Kendari.

2. Melakukan wawancara mendalam (in depth interview) kepada perusahaan daerah terkait.

3. Mencari strategi berdasarkan data yang didapatkan dan diteliti, untuk mengoptimalkan prinsip Tata Kelola Perusahaan yang Baik (Good Corporate Governance) agar dapat diaplikasikan dengan baik pada Perusahaan Daerah Kota Kendari agar dapat berpengaruh dengan kestabilan nilai PAD Kota Kendari.

Berdasarkan latar belakang di atas, yang menjadi titik fokus dalam penelitian ini adalah: Bagaimana strategi penerapan prinsip Good Corporate Governance dalam pengelolaan perusahaan daerah di Kota Kendari.

\section{Metode}

Tipe penelitian yang digunakan adalah normatif empiris, dengan metode pendekatan yang digunakan dalam penelitian ini adalah pendekatan perundang-undangan (statute aprroach) dan pendekatan kasus (case aprroach). Pendekatan perundang-undangan (statute aprroach) dilakukan dengan menelaah semua undang-undang dan regulasi yang bersangkut paut dengan isu hukum yang sedang ditangani. ${ }^{8}$ Sedangkan pendekatan kasus (case aprroach) dilakukan dengan cara melakukan telaah terhadap kasus-kasus yang berkaitan dengan isu yang dihadapi yang telah menjadi putusan pengadilan yang telah mempunyai kekuatan hukum yang tetap. ${ }^{9}$

\section{Konsep Prinsip Good Corporate Governance}

Sebagai konsep yang populer, GCG ternyata tidak mempunyai definisi yang tunggal: ${ }^{10}$

1. Menurut Komite Cadburry, melalui Cadburry Report pada tahun 1992 mendefinisikan GCG adalah prinsip yang mengarahkan dan mengendalikan perusahaan agar mencapai keseimbangan antara kekuatan serta kewenangan perusahaan agar mencapai keseimbangan antara kekuatan serta kewenangan perusahaan dalam memberikan pertanggungjawaban kepada para shareholders khususnya, dan stakeholders pada umumnya. Hal tersebut dimaksudkan untuk mengatur kewenangan direktur, manajer,

8 Peter Mahmud Marzuki, Penelitian Hukum (Jakarta: Kencana Prenada Media Group, 2009), 93.

9 Ibid., 39.

10 Toha, Penelitian Masalah Hukum Tentang Penerapan Good Corporate Governance Pada Dunia Usaha, 1011. 
pemegang saham, dan pihak lain yang berhubungan dengan perusahaan di lingkungan tertentu.

2. Center for European Policy Studies (CEPS), punya formula lain, menurutnya GCG adalah, merupakan seluruh sistem yang dibentuk mulai dari hak (right), proses, serta pengendalian, baik yang ada di dalam maupun di luar manajemen perusahaan. Sebagai catatan, hak di sini adalah hak seluruh stakeholders, bukan terbatas kepada shareholders saja. Hak adalah berbagai kekuatan yang dimiliki stakeholders, bukan terbatas kepada shareholders saja. Hak adalah berbagai kekuatan yang dimiliki stakeholders secara individual untuk mempengaruhi manajemen. Proses maksudnya adalah mekanisme dari hak-hak tersebut. Adapun pengendalian merupakan mekanisme yang memungkinkan stakeholders menerima informasi yang diperlukan seputar aneka kegiatan perusahaan.

3. Kelompok negara maju (OECD) mendefinisikan GCG sebagai cara-cara manajemen perusahaan bertanggung jawab pada shareholder-nya. Pengambilan keputusan cara manajemen perusahaan bertanggung jawab pada shareholder-nya. Pengambilan keputusan di perusahaan haruslah dapat dipertanggungjawabkan, dan keputusan tersebut mampu memberikan nilai tambah bagi shareholders. Karena itu fokus utama di sini terkait dengan proses pengambilan keputusan perusahaan yang mengandung nilai-nilai transparency, responsibility, accountability, dan tentu saja fairness. Asian Development Bank (ADB), menjelaskan bahwa GCG mengandung empat nilai yaitu accountability, transparency, predictability dan participation.

4. Finance Committee on Corporate Governance Malaysia, mengartikan GCG adalah merupakan suatu proses serta struktur yang digunakan untuk mengarahkan bisnis dan akuntabilitas perusahaan. Adapun tujuan akhirnya adalah menaikkan nilai saham dalam jangka panjang tetapi tetap memperhatikan berbagai kepentingan para stakeholder lainnya.

5. Pemerintah Indonesia dalam hal ini Menteri BUMN11, mengartikan "Good Corporate Governance, adalah suatu proses dan struktur yang digunakan oleh organ BUMN untuk meningkatkan keberhasilan usaha dan akuntabilitas perusahaan guna mewujudkan nilai pemegang saham dalam jangka panjang dan tetap memperhatikan kepentingan stakeholders lain, berdasarkan peraturan perundang-undangan dan nilai-nilai etika. Lembaga Keuangan Malaysia, mengartikan "Good Corporate Governance", adalah merupakan proses dan struktur yang digunakan untuk mengarahkan dan mengelola bisnis serta urusan- urusan perusahaan, dalam rangka meningkatkan kemakmuran bisnis dan akuntabilitas perusahaan, dengan tujuan utama mewujudkan nilai pemegang saham dalam jangka panjang dengan tetap memperhatikan kepentingan stakeholder yang lain.

6. Forum Corporate Governance, mengartikan "Good Corporate Governance" adalah lembaga atau institusi yang di dalamnya terdapat seperangkat peraturan-peraturan yang menetapkan hubungan antara pemegang saham, pengurus, pihak kreditur, pemerintah, karyawan serta para pemegang kepentingan internal dan eksternal

11 SK. Menteri BUMN N0. Kep-117/M-MBU/2002. 
lainnya sehubungan dengan hak-hak dan kewajiban mereka, atau dengan kata lain sistem yang mengarahkan dan mengendalikan perusahaan. ${ }^{12}$

Dari terminologi atau pengertian-pengertian yang diuraikan di atas, yang dimaksud Good Corporate Governance dalam penelitian ini adalah: Suatu institusi atau lembaga yang bermaksud mengarahkan pengelola bisnis serta urusan-urusan perusahaan dalam rangka keberhasilan usaha dan akuntabilitas untuk mewujudkan nilai pemegang saham dalam jangka panjang serta mempertahankan kepentingan stakeholder. Merupakan kumpulan norma atau kaidah, yang mengatur hubungan antara pemegang saham, pengurus, pihak kreditur, pemerintah, karyawan, serta para pemegang kepentingan internal dan ekstern. ${ }^{13}$

Good Corporate Governance adalah tata kelola yang baik (good corporate governance) merupakan struktur yang oleh stakeholder, pemegang saham, komisaris dan manajer menyusun tujuan perusahaan dan sarana untuk mencapai tujuan perusahaan dan sarana untuk mencapai tujuan tersebut dan mengawasi kinerja. Good Corporate Governance adalah suatu tata kelola lembaga atau perusahaan yang menerapkan prinsip-prinsip transparency, accountability, responsibility, independency, dan fairness (keadilan). ${ }^{14}$

Good Corporate Governance adalah prinsip yang mengarahkan dan mengendalikan perusahaan agar mencapai keseimbangan antara kekuatan serta kewenangan perusahaan dalam memberikan pertanggungjawabannya kepada shareholders khususnya, dan stakeholders pada umumnya. ${ }^{15} \mathrm{Hal}$ ini dimaksudkan pengaturan kewenangan direktur, manajer, pemegang saham, dan pihak lain yang berhubungan dengan perkembangan perusahaan. ${ }^{16}$ Good Corporate Governance (GCG) adalah suatu sistem yang mengatur mengelola dan mengawasi proses pengendalian usaha yang berjalan secara berkesinambungan (sustainable) untuk menaikkan nilai saham, sebagai bentuk pertanggungjawaban kepada shareholders tanpa mengabaikan kepentingan stakeholders yang meliputi karyawan, kreditur dan masyarakat.

12 Tedi Supriadi, "Pengaruh Mekanisme Good Corporate Governance Terhadap Ketepatan Waktu Penyampaian Laporan Keuangan (Studi Pada Perusahaan Manufaktur Sub Sektor Makanan dan Minuman Yang Terdaftar Di Bursa Efek Indonesia 2011-2015)” (Universitas Pasundan Bandung, 2017), 16.

13 Ibid., 17.

14 Wahyudin Zarkashi, Good Corporate Governance Pada Badan Usaha Manufaktur, Perbankan, dan Jasa Keuangan Lainnya (Bandung: Alfabeta, 2008), 55.

15 Nungky Wanodyatama Islami, “Menjadi BUMN Ber-Good Corporate Governance Terbaik," Jasa Tirta I, diakses Januari 10, 2020, http://bumn.go.id/jasatirta1/berita/687.

16 Abdul Latif dan Hapzi Ali, Penerapan Good Corporate Govermance PT. Antam Tbk. (Jakarta: Magister Manajemen, Universitas Mercu Buana, n.d.), 2. 
Tujuan dari Corporate Governance adalah untuk menciptakan nilai tambah bagi semua pihak yang berkepentingan (stakeholders). ${ }^{17}$ Sedangkan manfaat diberlakukan Corporate Governance adalah sebagai berikut: ${ }^{18}$

1. Meningkatkan kinerja perusahaan melalui terciptanya proses pengambilan keputusan yang lebih baik, meningkatkan efisiensi operasional perusahaan serta lebih meningkatkan pelayanan kepada stakeholders.

2. Mempermudah diperolehnya dana pembiayaan yang lebih murah sehingga dapat lebih meningkatkan nilai perusahaan.

3. Pemegang saham akan merasa puas dengan kinerja perusahaan karena sekaligus akan meningkatkan shareholders value dan deviden.

4. Mengembalikan kepercayaan investor untuk menanamkan modalnya di Indonesia.

Peraturan undang-undang kementerian BUMN tentang GCG yang diatur dalam UndangUndang No. 19 Tahun 2003 tentang Badan Usaha Milik Negara, yang menyatakan bahwa, untuk dapat mengoptimalkan perannya dan mampu mempertahankan keberadaannya dalam perkembangan ekonomi dunia yang semakin terbuka dan kompetitif, maka BUMN perlu menumbuhkan budaya korporasi dan profesional antara lain melalui pembenahan pengurusan dan pengawasannya.

Pengurusan dan pengawasannya BUMN harus dilakukan berdasarkan prinsip tata kelola perusahaan yang baik Good Corporate Governance (GCG) adapun indikator dan unsur dari GCG tersebut adalah transparancy (transparan), accountability (akuntabilitas), independency (independen), Responsibility (pertanggungjawaban), fairness (keadilan/kewajaran).

Menurut Keputusan Menteri BUMN Nomor: Kep.117/M-MBU/2002, prinsip Good Corporate Governance (GCG) merupakan kaidah, norma ataupun pedoman korporasi yang diperlukan dalam sistem pengelolaan BUMN yang sehat. Adapun prinsip dasar Good Corporate Governance adalah sebagai berikut: 19

a) Akuntabilitas (Accountability) yaitu kejelasan fungsi, pelaksanaan dan pertanggungjawaban organ sehingga pengelolaan perusahaan terlaksana secara efektif.

b) Transparansi (Transparency), yaitu keterbukaan dalam melaksanakan proses pengambilan keputusan dan keterbukaan dalam mengemukakan informasi materiil dan relevan mengenai perusahaan.

17 Supriadi, "Pengaruh Mekanisme Good Corporate Governance Terhadap Ketepatan Waktu Penyampaian Laporan Keuangan (Studi Pada Perusahaan Manufaktur Sub Sektor Makanan dan Minuman Yang Terdaftar Di Bursa Efek Indonesia 2011-2015)," 22.

18 Forum For Corporate Governance In Indonesia, Peranan Dewan Komisaris dan Komite Audit dalam Pelaksanaan Corporate Governance (Tata Kelola Perusahaan), 2 ed. (Jakarta: Forum For Corporate Governance In Indonesia, 2001), 4.

19 Imam Suwandi, Ria Arifianti, dan Muhamad Rizal, "Pelaksanaan Prinsip-Prinsip Good Corporate Governance (GCG) Pada PT. Asuransi Jasa Indonesia (JASINDO)," Jurnal Manajemen Pelayanan Publik 2, no. 1 (Juli 2, 2019): 48, http://jurnal.unpad.ac.id/jmpp/article/view/21559. 
c) Pertanggungjawaban (Responsibility), yaitu kesesuaian di dalam pengelolaan perusahaan terhadap peraturan perundang-undangan yang berlaku dan prinsipprinsip korporasi yang sehat.

d) Kemandirian (Independency), yaitu suatu keadaan dimana perusahaan dikelola secara profesional tanpa benturan kepentingan dan pengaruh atau tekanan dari pihak mana pun yang tidak sesuai dengan peraturan perundang-undangan yang berlaku dan prinsip-prinsip korporasi yang sehat.

e) Kesetaraan dan Kewajaran (Fairness), yaitu keadilan dan kesetaraan di dalam memenuhi hak-hak stakeholder yang timbul berdasarkan perjanjian dan peraturan perundang-undangan yang berlaku. ${ }^{20}$

Untuk mewujudkan prinsip-prinsip Good Corporate Governance, ada 6 (enam) pilar yang perlu dilaksanakan, yaitu:

1) Sistem perlindungan hak pemegang saham.

2) Visi, misi dan rencana strategis yang jelas.'

3) Kembangkan keseimbangan peran dan fungsi organ perusahaan.

4) Sistem akuntansi dan Management Information System yang menjamin transparansi.

5) Manajemen pengendalian risiko, kepatutan aturan dan sistem audit yang andal.

6) Sistem pengukuran kinerja dan pengembangan Sumber Daya Manusia.

Dalam pelaksanaannya penerapan prinsip Good Corporate Governance (GCG) di perusahaan adalah penting bagi perusahaan untuk melakukan tahapan yang cermat berdasarkan analisis atas situasi dan kondisi perusahaan, dan tingkat kesiapannya, sehingga penerapan GCG dapat berjalan lancar dan mendapatkan dukungan dari seluruh unsur di dalam perusahaan. ${ }^{21}$ Adapun tahapan-tahapan dalam pelaksanaan prinsip GCG yaitu sebagai berikut: 22

a. Tahap Persiapan

Tahapan ini terdiri dari 3 tahapan yaitu:

1) Awareness Building merupakan langkah sosialisasi awal untuk membangun kesadaran mengenai arti pentingnya GCG dan komitmen bersama dalam penerapannya. Upaya ini dapat dilakukan dalam meminta bantuan tenaga ahli independen dari luar perusahaan. Bentuk kegiatan dapat dilakukan melalui seminar, loka karya, dan diskusi kelompok.

20 Vivi Sulvianti dan Mahendra Putra Kurnia, "Implementasi Prinsip Good Corporate Governance (GCG) Pada PT. Pelita Jaya di Tarakan," Jurnal Beraja Niti 2, no. 11 (2013): 3-4.

21 Ahmad Daniri, Good Corporate Governance Konsep dan Penerapannya dalam Konteks Indonesia (Jakarta: Ray Indonesia, 2005), 30.

22 Chinn, 2000; Shaw 2003, dalam Thomas S. Kaihatu, "Good Corporate Governance dan Penerapannya di Indonesia," Jurnal Manajemen dan Wirausaha 8, no. 1 (2006): 3; Iva Yulia Munawarah, lihat juga di "Analisis Yuridis Terhadap Implementasi Prinsip Good Corporate Governance dalam Pengelolaan Perseroan Terbatas pada PT. Bukit Intan Indoperkasa Balikpapan Menurut Undang-Undang Nomor 40 Tahun 2007 Tentang Perseroan Terbatas," Jurnal Mahasiswa Fakultas Hukum Universitas Brawijaya (2006): 6-8. 
2) Assessment merupakan upaya untuk mengukur atau lebih tepatnya memetakan kondisi perusahaan dalam penerapan GCG saat ini. Langkah ini perlu guna memastikan titik awal atau untuk mengidentifikasi langkah-langkah yang tepat guna mempersiapkan infrastruktur dan struktur perusahaan yang kondusif bagi penerapan GCG secara efektif.

3) Manual buliding adalah langkah berikut setelah assessment dilakukan. Berdasarkan hasil pemetakan tingkat kesiapan perusahaan dan upaya identifikasi prioritas penerapannya, penyusunan manual atau pedoman implementasi GCG dapat disusun.

b. Tahap Implementasi

Tahap ini terdiri dari 3 langkah utama yakni:

1) Sosialisasi diperlukan untuk memperkenalkan kepada seluruh perusahaan berbagai aspek yang terkait dengan implementasi GCG di dalam perusahaan tersebut. Upaya sosialisasi perlu dilakukan dengan suatu tim khusus yang dibentuk untuk itu, langsung berada di bawah pengawasan direktur utama atau salah satu direktur yang ditunjuk sebagai GCG champion di perusahaan.

2) Implementasi adalah kegiatan yang dilakukan sejalan dengan pedoman GCG yang ada, berdasarkan roadmap yang telah disusun implementasi harus bersifat top down appoach yang melibatkan dewan komisaris dan direksi perusahaan. Implementasi hendaknya mencakup pula upaya manajemen perubahan (change management) guna mengawal proses perubahan yang ditimbulkan oleh implementasi GCG.

3) Internalisasi adalah tahap jangka panjang dalam implementasi, Internalisasi mencakup upaya-upaya untuk memperkenalkan GCG di dalam seluruh proses bisnis perusahaan melalui berbagai prosedur operasi (misalnya proses pengadaan, dan lain-lain), sistem kerja, dan berbagai peraturan perusahaan. Dengan upaya ini dapat dipastikan bahwa penerapan GCG bukan sekedar di permukaan atau sekedar suatu kepatuhan yang bersifat superficial, tapi benarbenar tercermin dalam seluruh aktivitas perusahaan.

c. Tahap Evaluasi

Tahap evaluasi adalah tahap yang perlu dilakukan secara teratur dari waktu ke waktu untuk mengukur sejauh mana efektivitas penerapan GCG telah dilakukan dengan meminta pihak independen melakukan audit implementasi dan scorsing atas praktik GCG yang ada.

Dalam hal membangun GCG, dan terkait dengan pengembangan sistem, diperlukan langkah-langkah sebagai berikut: ${ }^{23}$

1) Menerapkan visi-misi, rencana strategis, tujuan perusahaan, serta sistem operasional dalam pencapaiannya secara jelas.

23 Zarkashi, Good Corporate Governance Pada Badan Usaha Manufaktur, Perbankan, dan Jasa Keuangan Lainnya, 25. 
2) Mengembangkan suatu struktur yang menjaga keseimbangan peran dan fungsi organ perusahaan (check and balance).

3) Membangun sistem informasi, baik untuk keperluan proses pengambilan keputusan maupun keperluan keterbukaan informasi material dan relevan mengenai perusahaan.

4) Membangun sistem audit yang andal, yang tak terbatas pada kepatuhan terhadap peraturan dan prosedur operasi standar, tetapi juga mencakup pengendalian risiko perusahaan.

5) Membangun sistem yang melindungi hak-hak pemegang saham secara adil dan setara di antara para pemegang sah.

6) Membangun sistem pengembangan SDM, termasuk pengukuran kinerjanya.

\section{Strategi Penerapan Prinsip Good Corporate Governance Dalam Pengelolaan Perusahaan Daerah di Kota Kendari}

Penerapan GCG sudah jelas diatur menurut peraturan Menteri peraturan menteri negara BUMN Nomor PER-01/MBU/2011 tentang penerapan tata kelola perusahaan yang baik (Good Corporate Governance) pada badan usaha milik negara, pada tahun 2014, telah tertib undang-undang 23 tahun 2014 tentang pemerintah daerah dalam Undang-Undang tersebut BUMD disebutkan badan usaha yang seluruh atau sebagian besar modalnya dimiliki oleh daerah. Bentuk dari BUMD menurut Undang-Undang tersebut dapat berupa perusahaan umum daerah (seluruhnya modal dimilik satu daerah) dan perusahaan perseroan daerah (berbentuk PT dengan saham seluruhnya atau paling sedikit $51 \%$ dimiliki satu daerah).

Di dalam Pasal 343 Undang-Undang mengatur mengenai penerapan GCG di BUMD disebutkan bahwa pengelolaan BUMD paling sedikit harus memenuhi unsur:

1. Tata cara penyertaan modal;

2. Organ dan kepegawaian;

3. Tata cara evaluasi;

4. Tata kelola perusahaan yang baik;

5. Perencanaan, pelaporan, pembinaan dan pengawasan.

6. Kerja sama

7. Penggunaan laba

8. Penugasan pemerintah daerah

9. Pinjaman

10. Satuan pengawas intern, komite audit, dan komite lainnya

11. Penilaian tingkat kesehatan, restrukturisasi dan privatisasi.

12. Perubahan bentuk hukum

13. Kepailitan dan

14. Penggabungan, peleburan dan pengambilalihan. 
Terkait dengan GCG maka unsur "tata kelola perusahaan yang baik" merupakan unsur yang harus ada dalam pengelolaan BUMD, nah jika dalam Undang-Undang, maka yang dibutuhkan selanjutnya dalam penerapannya adalah adanya peraturan turunan, baik peraturan pemerintah ataupun peraturan daerah. BUMD yang berbentuk perusahaan umum daerah seperti PD Pasar dan PDAM Tirta Anoa Kendari, pengelolaannya harus tunduk pada peraturan daerah tempat BUMD tersebut berada, pengawasan dan pembinaan dari BUMD bentuk ini oleh kepala daerah selaku wakil daerah Pengawasan dan pembinaan dari BUMD bentuk ini dilakukan oleh Kepala Daerah selaku wakil daerah sebagai pemilik modal, direksi, dan dewan pengawas.

Kepala Daerah bisa melakukan intervensi terhadap kebijakan atau strategi yang diambil oleh BUMD untuk kepentingan daerahnya. Jadi, keseriusan dalam penerapan GCG untuk BUMD bentuk ini sangat bergantung pada komitmen dari Pemerintah Daerah tempat BUMD tersebut bernaung. Sedangkan untuk BUMD yang berbentuk Perusahaan Perseroan Daerah diwajibkan untuk tunduk pada Undang-undang Nomor 40 Tahun 2007 tentang Perseroan Terbatas. Hal yang berkaitan dengan GCG dalam UU PT dan peraturan pelaksanaannya adalah: "Bahwa berlakunya undang-undang ini, anggaran dasar Perseroan, dan ketentuan peraturan perundang-undangan ini, tidak mengurangi kewajiban setiap perseroan untuk menaati asas itikad baik, asas kepantasan, asas kepatutan, dan prinsip tata kelola perseroan yang baik (GCG) dalam menjalankan perseroan". 24

Dengan kata lain, BUMD yang berbentuk perusahaan perseroan daerah memiliki kewajiban untuk menerapkan GCG, baik berdasarkan UU Pemerintah Daerah maupun UU Perseroan Terbatas. Apakah pemerintah daerah telah menyadari itu? Apakah pemerintah daerah telah memiliki komitmen untuk melaksanakan kewajiban tersebut? Padahal, apabila pemerintah daerah maupun pengelola BUMD dapat menyadari, penerapan GCG dapat menaikkan nilai perusahaan dan menarik minat investor. Apalagi kalau BUMD tersebut memiliki rencana atau telah menjadi perusahaan terbuka, maka penerapan GCG akan memegang peranan yang lebih penting lagi. ${ }^{25}$ Pengelolaan perusahaan berprinsip GCG memiliki beberapa macam tujuan: ${ }^{26}$

1. Melindungi hak dan kepentingan pemegang saham.

2. Melindungi hak dan kepentingan para anggota the stakeholders non pemegang saham.

3. Meningkatkan nilai perusahaan dan para pemegang saham.

4. Meningkatkan efisiensi dan efektivitas kerja dewan pengurus dan manajemen perusahaan.

5. Meningkatkan mutu hubungan dengan antar karyawan perusahaan.

24 M Tasya Renaldo KM, "Wajibkah menerapkan Good Corporate Governance pada BUMD?," TataKelola.co, diakses Januari 10, 2020, https://tatakelola.co/manajemen-risiko/wajibkah-menerapkan-goodcorporate-covernance-pada-bumd.

25 Ibid.

26 Eka Hardikasari, dalam Arif Saripudin, "Pengaruh Good Corporate Governance Terhadap Profitabilitas (Studi Pada Perusahaan Pertambangan di Bursa Efek Indonesia)" (Universitas Pasundan, 2014), 30-31. 
Sekarang yang menjadi pertanyaan, apakah pengelola BUMD maupun Pemerintah Daerah Kota Kendari telah menyadari pentingnya penerapan GCG bagi perusahaan daerah Kota Kendari? Sekali lagi, tingkat kepentingan penerapan GCG di BUMD sangat dipengaruhi oleh pemahaman dan komitmen dari pemilik dan pengelola BUMD oleh karena itu ketika pemahaman terhadap dimiliki oleh pemerintah daerah maka akan ada pelaksanaan. ${ }^{27}$

Prinsip GCG juga mensyaratkan bahwa perusahaan selalu memastikan bahwa pengelolaan perusahaan dilakukan secara independen bebas dari intervensi sehingga masing-masing organ atau divisi perusahaan tidak saling mendominasi dan tidak dapat diintervensi oleh pihak maupun bidang lain. Di perusahaan, kepentingan pemegang saham dan pemangku kepentingan lainnya selalu mendapatkan perhatian khusus. Perseroan juga selalu menerapkan perlakuan yang setara dan sewajarnya, baik kepada publik, otoritas pasar modal, komunitas pasar modal, maupun para pemangku kepentingan. Sementara itu hubungan dengan karyawan dijaga dengan memperhatikan hak dan kewajibannya secara adil dan wajar. ${ }^{28}$

Hal ini menjadi syarat PD Pasar Kota Kendari dalam penerapan GCG di perusahaannya karena sampai saat ini masih banyak intervensi/belum mandiri ataupun terjadi pengambilalihan kewenangan dari PD Pasar Kota Kendari seperti adanya organisasi perangkat Daerah yang melakukan pengelolaan pasar di Kota Kendari yang kalau kita kaji berdasar perda Nomor 03 Tahun 2004 Tentang Pembentukan Perusahaan Daerah Pasar Kota Kendari, maka dalam Pasal 5 menyebutkan tujuan didirikan PD Pasar yaitu mewujudkan dan meningkatkan pelayanan umum kepada masyarakat dalam upaya memenuhi kebutuhan jasa sarana dan prasarana serta fasilitas penunjang lainnya di bidang pasar.

Pasal 6 menyebutkan bahwa untuk mencapai tujuan dimaksud dalam Pasal 5, perusahaan daerah ini bergerak dalam lapangan usaha dan pelayanan umum dibidang pasar. Dan kalau kita lihat lagi dalam perda Nomor 16 tahun 2006 tentang pengurusan pasar dalam wilayah Kota Kendari khususnya dalam Pasal 3 maka seluruh wewenang pengurusan pasar, didelegasikan oleh Walikota kepada direksi PD Pasar dan dimana kewenangannya tersebut meliputi:

1. Tempat-tempat berjualan/berusaha dalam pasar;

2. Pembagian tempat berjualan dalam pasar;

3. Pengelompokan jenis jualan dalam pasar;

4. Penggunaan areal/pelataran dan bangunan pasar dan perparkiran;

5. Surat izin tempat berjualan/usaha dipasar berdasarkan peraturan daerah;

6. Tarif jasa penggunaan/pemanfaatan fasilitas pasar berdasarkan peraturan daerah;

7. Perbaikan/rehabilitasi bangunan, sarana dan prasarana pasar;

8. Pemasangan dan pemanfaatan fasilitas umum pasar;

27 KM, "Wajibkah menerapkan Good Corporate Governance pada BUMD?"

28 "Tata Kelola Perusahaan yang Baik," Sarana Multigriya Finansial, diakses Januari 10, 2020, https://smfindonesia.co.id/korporasi/tata-kelola-perusahaan-yang-baik. 
9. Waktu operasi, jam buka dan tutup pasar;

10. Pengelolaan atas penggunaan/pemanfaatan fasilitas pasar;

11. Besaran kontribusi/iuran atas pusat perbelanjaan.

PDAM Tirta Anoa Kendari menghadapi masalah pengaliran air yang tidak merata pada daerah layanan. Penyebab dari permasalahan ini adalah:

1. Kerusakan dan kebocoran pada pipa;

2. Kerusakan pada meter air pelanggan;

3. Pembacaan meter air pelanggan yang tidak akurat;

4. Pembagian air kurang berjalan baik.

Untuk mengatasi permasalahan di atas, PDAM Tirta Anoa tidak bisa mengandalkan dana dari perusahaan itu sendiri artinya bahwa terdapat keterbatasan dana digunakan untuk biaya operasional sehari-hari. Permasalahan berikutnya yaitu terkait dengan tingginya biaya produksi air baku dan debit air baku tidak stabil, penghentian pengaliran air akibat perbaikan pipa. Penyebab dari permasalahan yaitu:

1. Tingginya pemakaian biaya listrik untuk memompa air baku ke WTP (pengolahan);

2. Sarana dan prasarana produksi sering mengalami gangguan teknis;

3. Kebocoran akibat pipa pecah;

4. Kebocoran distribusi pada pipa yang berusia tua.

Masalah lainnya yaitu dalam aspek manajemen adalah kinerja karyawan PDAM yang masih rendah. Hal ini disebabkan:

1. Penghasilan karyawan yang belum memadai;

2. Penerimaan pegawai tidak sesuai dengan kondisi dan kebutuhan perusahaan;

\subsection{Perusahaan Daerah (PD) Pasar Kota Kendari}

Berbagai permasalahan dihadapi oleh PD Pasar terutama dalam hal kewenangan yang masih tumpang tindih dengan instansi terkait. Selain itu permasalahan, pelayanan, anggaran dan belum optimalnya SDM menjalankan tugasnya masih terjadi dalam pengelolaan PD Pasar Kota Kendari. Sehingga PD Pasar perlu melakukan evaluasi perbaikan agar optimal dalam menerapkan prinsip-prinsip GCG dalam hal, kewenangan, pelayanan, anggaran dan peningkatan Kapasitas SDM (sisi tingkat pendidikan karyawan, kemampuan dalam berinovasi) dengan langkah-langkah sebagai berikut:

1. Mempertegas kewenangan PD Pasar, dengan upaya:

1) PD pasar mendorong perbaikan aspek kelembagaan melalui Peraturan Daerah agar tidak terjadi tumpang tindih kewenangan;

2) PD Pasar mendorong peningkatan kerja sama dengan pemerintah daerah melalui penyertaan modal;

3) PD Pasar mendorong peningkatan kemandirian dan tanggung jawab melalui peraturan daerah; 
4) PD Pasar memberikan sanksi terhadap adanya pelanggaran aturan oleh para pedagang.

2. Pengembangan konsep pasar sebagai koridor ekonomi atau pasar wisata dengan meningkatkan kebersihan dan penambahan sarana atau prasarana, dengan upaya:

1) Meningkatkan kebersihan pasar dengan membangun sistem kebersihan pasar yang lebih efektif;

2) PD Pasar membuat action plan dengan mengacu pada strategi berdasarkan usulan dari Unit kerja PD Pasar;

3) PD Pasar melakukan sosialisasi secara rutin kepada para pedagang (Hunian pasar) yang berkaitan dengan masalah kebersihan, kesehatan dan pencegahan kebakaran;

4) Meningkatkan anggaran untuk perbaikan dan penambahan sarana dan prasarana pasar tradisional disertai perbaikan sistem keamanan terhadap bahaya kebakaran;

5) Menata ulang areal parkir agar memberikan kenyamanan dan keamanan pemilik kendaraan bermotor;

6) PD Pasar menangani mengelola keluhan pelanggan melalui kepala Unit pasar yang tersebar di seluruh Kota Kendari;

7) Mempersiapkan dan membuat proses bisnis terkait keadaan/kondisi emergensi/darurat/bencana.

3. Penataan dan renovasi pasar yang bertujuan memudahkan konsumen dalam berbelanja, dengan upaya:

1) Membangun sistem pelayanan antara pedagang dan konsumen agar hubungan tetap terjaga;

2) Menata ulang zona produk yang dijual agar memudahkan konsumen dalam berbelanja dan meningkatkan nilai jual toko.

4. Memberikan katalog berisi informasi produk yang dijual yang dilengkapi dengan lokasi toko atau stand, dengan upaya:

1) Memanfaatkan teknologi informasi melalui website atau media sosial dalam mempromosikan kondisi pasar yang ditawarkan kepada calon pedagang;

2) PD Pasar harus melibatkan pelanggan dalam mengembangkan dan menawarkan produk dan layanan yang sesuai dengan harapan pelanggan.

5. Peningkatan kompetensi SDM PD Pasar, dengan upaya:

1) Peningkatan kompetensi SDM PD Pasar yang berbasis teknologi informasi;

2) PD Pasar harus melakukan pengembangan karyawan untuk meningkatkan kapabilitas melalui training;

3) PD Pasar melakukan proses recruitment sesuai dengan pedoman Kebijakan Kepegawaian;

4) PD Pasar harus membuat ukuran kinerja karyawan;

5) PD Pasar melakukan review kinerja dan realisasi rencana kerja;

6) PD Pasar melakukan diskusi bersama karyawan dan para Unit pasar menggali ideide untuk menyelesaikan masalah di lapangan. 
6. Meningkatkan alokasi anggaran untuk promosi dan komponen lain dalam usaha meningkatkan kemampuan bersaing pasar tradisional terhadap pasar modern, dengan upaya:

1) PD Pasar melaksanakan rencana kerja dengan memperhitungkan anggaran yang tersedia dan mengalokasikan sumber daya manusia serta keuangan dalam mencapai sasaran perusahaan;

2) PD Pasar merancang produk yang berkaitan dengan meningkatkan hunian pasar dan meningkatkan mutu pelayanan.

7. PD Pasar membangun kerja sama dengan lembaga keuangan dalam pembiayaan pedagang, dengan upaya:

1) Mendorong peningkatan produk penjualan;

2) Peningkatan pengawasan terhadap laporan keuangan PD Pasar;

3) Peningkatan akses permodalan bagi pedagang.

8. Membangun kerja sama antara pedagang dengan pemasok dan pengelola pasar tradisional swasta, dengan upaya:

1) Memperbaiki jaringan distribusi pedagang tradisional sehingga memiliki daya tawar lebih baik dengan pemasok;

2) Memperbaiki kemitraan dengan pemasok dan pengelola pasar tradisional swasta.

\subsection{Perusahaan Daerah Air Minum (PDAM) Tirta Anoa Kota Kendari}

Berbagai permasalahan dihadapi oleh PDAM Tirta Anoa terutama dalam hal:

1) Biaya infrastruktur minim. PDAM Tirta Anoa saat ini, masuk dalam kategori PDAM Sakit yang sebelumnya masuk dalam kategori PDAM kurang sehat dengan nilai/skor 2, 27. Artinya bahwa terjadi penurunan status kinerja PDAM Tirta Anoa dalam memenuhi kebutuhan air masyarakat Kota Kendari. Hal ini dapat disebabkan karena infrastruktur yang belum memadai yang dapat berakibat pada sistem pelayanan yang tidak optimal. Saat ini PDAM Tirta Anoa hanya mengoperasikan1 (satu) pipa (jalur utama penyaluran/pendistribusian air bersih) untuk melayani masyarakat Kota Kendari. Kondisi ini, memperburuk sistem pelayanan PDAM Tirta Anoa (sebagai operator air minum) untuk pemenuhan masyarakat sebagai pelanggan di Kota Kendari. Kondisi jaringan pipa yang sudah mulai rusak/berusia lama menjadi salah satu penyebab menurunnya kinerja pelayanan PDAM Tirta Anoa.

2) Biaya operasional tinggi. Minimnya dana operasional yang dikelola oleh PDAM Tirta Anoa, berpengaruh pada sistem pelayanan terhadap pelanggan yang tidak optimal terutama dalam hal adanya pengaduan dari masyarakat sebagai pelanggan terhadap terjadinya kebocoran pipa sampai pada penyaluran air ke rumah-rumah pelanggan yang tidak optimal. Terhadap adanya pengaduan masyarakat, PDAM Tirta Anoa masih lambat dalam proses penanganannya karena minimnya dana operasional terutama dalam hal terjadinya kebocoran pipa dan penyambungan pipa ke rumah-rumah pelanggan. Kondisi ini diperparah dengan tingginya tarif listrik, dimana tarif listrik yang dibebankan kepada PDAM Tirta Anoa adalah tarif industri, sedangkan mayoritas pelanggan di Kota Kendari adalah golongan tarif rumah tangga. 
Kendala operasional lain yang dihadapi PDAM Tirta Anoa Kota Kendari yaitu pengaliran air yang tidak merata pada daerah layanan, yang disebabkan kerusakan dan kebocoran pada pipa, kerusakan pada meter air pelanggan, pembacaan Meter Air Pelanggan yang tidak akurat, pembagian air kurang berjalan baik. Untuk mengatasi permasalahan di atas, PDAM Tirta Anoa tidak bisa mengandalkan dana dari perusahaan itu sendiri artinya bahwa terdapat keterbatasan dana digunakan untuk biaya operasional sehari-hari.

3) Kurangnya dukungan stakeholder. Kurangnya dukungan stakeholder, terutama terhadap biaya operasional PDAM Tirta Anoa menjadi salah satu penyebab tidak optimalnya pelayanan yang dilakukan oleh PDAM Tirta Anoa. Pemerintah daerah Kota Kendari melalui Peraturan Daerah No.1 tahun 2014 tentang Penambahan penyertaan modal pemerintah daerah kepada PDAM Tirta Anoa Kota Kendari, telah menambah penyertaan modal berupa uang dan barang namun belum optimal karena belum tercipta secara optimal independen dalam pengelolaannya.

Solusi terhadap permasalahan dan kendala dapat dilakukan dengan upaya sebagai berikut:

1. Peran pemerintah Kota Kendari:

1) Dengan otonomi daerah, kewenangan penyediaan air adalah pada pemerintah daerah Kota Kendari melalui PDAM Tirta Anoa sebagai operator. Tetapi masih terlihat bahwa pemerintah daerah Kota Kendari belum memandang air sebagai persoalan prioritas. Pemerintah daerah Kota Kendari harus mampu menjamin berlakunya supremasi hukum (payung hukum) yang konsisten dan efektif terhadap pemenuhan kebutuhan air khususnya air minum terhadap masyarakat di Kota Kendari. Khususnya terkait dengan pengaturan secara lebih konkret terkait dengan biaya infrastruktur dan biaya operasional. Hal ini sebagai upaya untuk mengembangkan kebijakan dan peraturan yang dapat menciptakan lingkungan yang kondusif dan dapat meningkatkan praktik-praktik GCG di PDAM Tirta Anoa.

2) Perlu adanya kebijakan yang memihak kepada masyarakat terutama masyarakat miskin. Karena pada dasarnya negara menjamin hak setiap orang untuk mendapatkan air bagi kebutuhan pokok minimal sehari hari guna memenuhi kehidupan yang sehat, bersih dan produktif. Sehingga harus ada penyetaraan dalam membayar antara masyarakat berpenghasilan tinggi dan berpenghasilan rendah. Agar tercapai keadilan masyarakat berpenghasilan rendah harus menjadi prioritas. Saat ini, walaupun sudah terdapat program-program air minum untuk masyarakat berpenghasilan rendah, namun akses terhadap air minum belum menunjukkan peningkatan yang berarti. Perlu dukungan kebijakan yang lebih fokus untuk penyediaan air minum bagi masyarakat berpenghasilan rendah.

3) PDAM Tirta Anoa belum mandiri karena campur tangan pemilik (Pemda) Kota Kendari dalam manajemen dan keuangan, hal ini cukup membebani PDAM Tirta Anoa. Dari segi keuangan, tarif air saat ini tidak bisa menutup biaya operasi PDAM, sehingga PDAM mengalami defisit kas. Selain itu, walaupun PDAM Tirta Anoa 
sudah terbentuk forum pelanggan/konsumen, namun perannya belum maksimal, belum dianggap mitra kerja PDAM yang potensial. Sehingga perlu kebijakan khususnya pada aspek pengawasan/akuntabilitas terhadap pengelolaan penyedia air minum oleh pemerintah daerah Kota Kendari. Selain itu, perlu ada penegasan sanksi untuk penyelenggara air minum yang tidak memberikan pelayanan sesuai dengan syarat yang ditentukan.

4) Perlu adanya keterlibatan pemerintah dalam peningkatan Kualitas Air untuk memenuhi Syarat Air Minum. Pemerintah daerah dapat berkontribusi melalui peningkatan biaya infrastruktur bagi PDAM Tirta Anoa yang tentunya dengan pengelolaan secara mandiri. Saat ini kualitas yang diterima pelanggan dari PDAM Tirta Anoa masih berkualitas air bersih, belum memenuhi syarat kualitas air minum. Padahal di dalam peraturan sudah diisyaratkan bahwa yang dimaksud dengan air minum adalah air yang bisa dikonsumsi tanpa dimasak terlebih dahulu. Selain itu, pemerintah perlu memberikan pemahaman akan hak haknya untuk memperoleh air yang sesuai dengan persyaratan air minum yang ada, sehingga masyarakat tidak menerima apa saja yang diterima dari penyedia air minum.

5) Perlu kebijakan Kemitraan antara Pemerintah dan Masyarakat Dalam Penyediaan Air Minum. Hal ini dilakukan untuk mencapai akses keterbukaan kepada masyarakat. Karena saat ini peran serta masyarakat dalam penyelenggaraan penyediaan air minum masih terbatas. Kelembagaan masyarakat yang terlibat dan berkecimpung dalam penyediaan air minum tidak berkembang. Di samping itu, sebagian masyarakat sebagai pelanggan di Kota Kendari masih menganggap bahwa air hanya urusan pemerintah daerah Kota Kendari atau PDAM Tirta Anoa, sehingga tidak tergerak untuk mengatasi masalah air minum secara bersama. Keterlibatan perempuan di Kota Kendari sebagai pengguna utama dan pengelola air minum dalam skala rumah tangga, pada setiap tahapan pengembangan penyediaan air minum masih sangat kurang.

2. Peran PDAM Tirta Anoa Kota Kendari

PDAM Tirta Anoa perlu melakukan evaluasi dan perbaikan agar optimal dalam menerapkan prinsip-prinsip GCG, dengan langkah-langkah sebagai berikut:

1) PDAM Tirta Anoa dalam sistem pengelolaan pegawai harus memiliki pola yang jelas, dengan upaya:

a) Pendidikan dan pelatihan untuk meningkatkan kapasitas dan kapabilitas sumber daya manusia pegawai;

b) Job desk yang sesuai dengan SOP dan aturan terkait.

2) Peningkatan keuangan Pendapatan/laba, dengan upaya:

a) peningkatan jumlah pelanggan melalui cara promosi dan sosialisasi kepada warga masyarakat;

b) peningkatan tarif air yang didasarkan pada efisiensi biaya;

c) Menambah jaringan pipa distribusi untuk meningkatkan luas jaringan dan meningkatkan tekanan air di wilayah yang bertekanan rendah;

d) Bekerja sama dengan tim audit untuk mengawasi laporan keuangan; 
e) Peningkatan pengawasan oleh SPI terhadap kinerja pegawai.

3) Peningkatan pelayanan melalui sistem informasi terhadap pelanggan, dengan upaya:

a) Pengaduan pelanggan yang dapat dilakukan secara on-line;

b) Pembayaran/penagihan melalui billing system;

c) Melakukan pengawasan rutin dan berkala pada jaringan pipa distribusi.

4) Peningkatan operasional, dengan upaya:

a) Penyertaan modal khususnya untuk dana operasional pegawai oleh pemerintah Kota Kendari;

b) Melakukan efisiensi biaya operasional;

c) Melakukan pembacaan meter induk secara rutin, mengganti jaringan pipa yang mengalami kebocoran dengan melaksanakan rehabilitasi dan reposisi jaringan pipa distribusi;

d) Melaksanakan kegiatan Step Test, untuk mencari dan menghitung kebocoran air;

e) Melakukan revisi SOP pembacaan meter air pelanggan dengan menggunakan kamera digital;

f) Membuat satuan tugas tim yang bertugas untuk memantau setiap saat adanya kebocoran sehingga kebocoran dapat segera ditangani.

5) Peningkatan kompetensi SDM, dengan upaya:

a) Peningkatan kompetensi SDM yang berbasis teknologi informasi;

b) Menambahkan kriteria dalam penilaian kinerja pegawai;

c) Peningkatan alokasi biaya diklat pegawai;

d) pemerataan keikutsertaan diklat bagi pegawai;

e) Melaksanakan In House Training.

\section{Penutup}

Strategi penerapan prinsip Good Corporate Governance dalam pengelolaan perusahaan daerah di Kota Kendari diperlukan pemahaman bersama antara Pemerintah Daerah Dan BUMD tentang pentingnya penerapan prinsip Good Corporate Governance. Selain itu, perlunya peraturan daerah secara khusus mengatur tentang pengaturan Penerapan Praktik Good Corporate Governance pada Badan Usaha Milik Daerah (BUMD) di Lingkungan Pemerintah Kota Kendari. Dalam hal kewenangan PD Pasar dan PDAM Tirta Anoa, perlu dipertegas dengan kembali merujuk Peraturan Daerah Nomor 03 Tahun 2004 Tentang Pembentukan Perusahaan Daerah Pasar Kota Kendari Tirta Anoa Kota Kendari Dibentuk melalui Peraturan Daerah Kota Kendari Nomor 3 Tahun 1976 Tentang Perusahaan Air Minum (PAM) Daerah Kabupaten Tingkat II Kendari Serta Peraturan Daerah Nomor 3 Tahun 2010.

Hal yang perlu diperhatikan adalah Pemerintah Daerah Kota Kendari harus membentuk PERWALI (Peraturan Wali Kota) atau Peraturan daerah yang mengatur Praktik Good Corporate Governance pada Badan Usaha Milik Daerah (BUMD) di Lingkungan Pemerintah Kota Kendari. Selain itu, menertibkan organisasi perangkat daerah yang terlibat langsung 
atau melakukan pola dominan dalam pengelolaan pasar dan air minum serta Memberikan seluruh kewenangan Pengelolaan Pasar Dan Air Minum kepada PD Pasar dan PDAM Tirta Anoa Kendari berdasar Peraturan Daerah Nomor 03 Tahun 2004 Tentang Pembentukan Perusahaan Daerah Pasar Kota Kendari Tirta Anoa Kota Kendari Dibentuk Melalui Peraturan Daerah Kota Kendari Nomor 3 Tahun 1976 Tentang Perusahaan Air Minum (PAM) Daerah Kabupaten Tingkat II Kendari Serta Peraturan Daerah Nomor 3 Tahun 2010.

\section{Daftar Pustaka}

Daniri, Ahmad. Good Corporate Governance Konsep dan Penerapannya dalam Konteks Indonesia. Jakarta: Ray Indonesia, 2005.

Forum For Corporate Governance In Indonesia. Peranan Dewan Komisaris dan Komite Audit dalam Pelaksanaan Corporate Governance (Tata Kelola Perusahaan). 2 ed. Jakarta: Forum For Corporate Governance In Indonesia, 2001.

Hasanah, Sovia. "Kepemilikan 100 Persen Saham BUMD oleh Satu Daerah." $\begin{array}{llll}\text { HukumOnline.com. } & \text { Jiakses } & & \end{array}$ https://www.hukumonline.com/klinik/detail/ulasan/lt59c1d986cb252/kepemilika n-100-persen-saham-bumd-oleh-satu-daerah.

Ikatan Banking Indonesia. Manajemen Risiko 2. Jakarta: Gramedia Pustaka Utama, 2015.

Islami, Nungky Wanodyatama. "Menjadi BUMN Ber-Good Corporate Governance Terbaik." Jasa Tirta I. Diakses Januari 10, 2020. http://bumn.go.id/jasatirta1/berita/687.

Kaihatu, Thomas S. "Good Corporate Governance dan Penerapannya di Indonesia." Jurnal Manajemen dan Wirausaha 8, no. 1 (2006).

KM, M Tasya Renaldo. "Wajibkah menerapkan Good Corporate Governance pada BUMD?" TataKelola.co. Diakses Januari 10, 2020. https://tatakelola.co/manajemenrisiko/wajibkah-menerapkan-good-corporate-covernance-pada-bumd.

Latif, Abdul, dan Hapzi Ali. Penerapan Good Corporate Govermance PT. Antam Tbk. Jakarta: Magister Manajemen, Universitas Mercu Buana, n.d.

Marzuki, Peter Mahmud. Penelitian Hukum. Jakarta: Kencana Prenada Media Group, 2009.

Munawarah, Iva Yulia. “Analisis Yuridis Terhadap Implementasi Prinsip Good Corporate Governance dalam Pengelolaan Perseroan Terbatas pada PT. Bukit Intan Indoperkasa Balikpapan Menurut Undang-Undang Nomor 40 Tahun 2007 Tentang Perseroan Terbatas,." Jurnal Mahasiswa Fakultas Hukum Universitas Brawijaya (2006).

Njatrijani, Rinitami, Bagus Rahmanda, dan Reyhan Dewangga Saputra. "Hubungan Hukum dan Penerapan Prinsip Good Corporate Governance dalam Perusahaan." Jurnal Gema Keadilan 6, no. 3 (2019).

Nur, Turiman Fachturaman. Terobosan Hukum Memajukan BUMD dalam Era Otonomi Daerah. Jakarta: Rajawali Garuda Pancasila, 2009.

Saripudin, Arif. "Pengaruh Good Corporate Governance Terhadap Profitabilitas (Studi Pada Perusahaan Pertambangan di Bursa Efek Indonesia).” Universitas Pasundan, 
2014.

Sulvianti, Vivi, dan Mahendra Putra Kurnia. "Implementasi Prinsip Good Corporate Governance (GCG) Pada PT. Pelita Jaya di Tarakan." Jurnal Beraja Niti 2, no. 11 (2013).

Supriadi, Tedi. "Pengaruh Mekanisme Good Corporate Governance Terhadap Ketepatan Waktu Penyampaian Laporan Keuangan (Studi Pada Perusahaan Manufaktur Sub Sektor Makanan dan Minuman Yang Terdaftar Di Bursa Efek Indonesia 2011-2015)." Universitas Pasundan Bandung, 2017.

Suwandi, Imam, Ria Arifianti, dan Muhamad Rizal. "Pelaksanaan Prinsip-Prinsip Good Corporate Governance (GCG) Pada PT. Asuransi Jasa Indonesia (JASIND0)." Jurnal Manajemen Pelayanan Publik 2, no. 1 (Juli 2, 2019): 45. http://jurnal.unpad.ac.id/jmpp/article/view/21559.

Toha, Suherman. Penelitian Masalah Hukum Tentang Penerapan Good Corporate Governance Pada Dunia Usaha. Jakarta: Pusat Penelitian Dan Pengembangan Hukum Badan Pembinaan Hukum Nasional Departemen Hukum dan HAM RI, 2005.

Zarkashi, Wahyudin. Good Corporate Governance Pada Badan Usaha Manufaktur, Perbankan, dan Jasa Keuangan Lainnya. Bandung: Alfabeta, 2008.

“Tata Kelola Perusahaan yang Baik.” Sarana Multigriya Finansial. Diakses Januari 10, 2020. https://smf-indonesia.co.id/korporasi/tata-kelola-perusahaan-yang-baik. 